\section{Ocio y arquitectura}

Patricio Cáraves Profesor, Pontificia Universidad Católica de Valparaíso

Los actos propios del ocio y de su forma de ocupar el espacio son muy variados. La observación de ellos por parte de los arquitectos da lugar a espacios específicos con nombres propios. Desde distintas áreas del arte se ilustran algunas de las formas de dar casa al ocio.

Para tratar el ocio en la arquitectura es propio verlo en un acto y referido a una obra. Lo que requiere un tiempo, para destinarlo libremente a la contemplación. En el ocio se busca lo despejado del espacio pero en cobijo, esto es, dar gobierno al espacio tridimensional, haciendo coexistir las lejanías con lo próximo.

Traigamos a presencia un hecho vivido probablemente por muchos,, un hecho corriente: el paseo de dos amigos o de una pareja. Al describirlo podemos anotar que caminan sin prisa, como queriendo posar la planta del pie enteramente en cada paso. Conversando distraídamente, en un intento libre de decir las palabras reposadamente, de modo que al oírlas casi se distingan sus sílabas. Mirando en la confianza del que se sabe en un paisaje vuelto un panorama familiar, despojado de lo extraño que pudiera provocar alguna tensión.

Yendo y viniendo, oyendo y hablando, dejándose llevar por el aroma de flores vecinas, mirando en una continuidad las lejanías con la cercanía. Palpando lo que esté al alcance de la mano. Y todo ello en medio de la distracción, bajo una luz matizada al amparo del follaje de un árbol. Se va por un espacio confiadamente, abierto al placer que permite disfrutar la extensión.

Este acto del paseo lo podemos ubicar tanto en una playa junto al mar, como en un parque, es decir, en la naturaleza. La diversidad de espacios para este acto es amplia. Lo hasta aquí expuesto es sin presencia de la arquitectura.

Ahora bien, nos preguntamos ¿cómo la arquitectura ampara al ocio?

El oficio de la arquitectura parte observando en lo ya descrito del paseo; así lo vuelve presente, es decir, acto paseo. Dar casa al acto de distensión que es el del paseo, en la total abertura de los sentidos, puesto que es lo propio de quien pasea. Para llevar a cabo esta faena presta atención a todo. Se observa lo que allí ocurre y nada elude. Es por ello que comienza nombrando para dar con una forma que dé cabida a la forma extensa, otorgándole la orientación. La extensión orientada debemos entenderla como la complejidad de la forma que cobija al ojo, invitando al pie a dar los pasos en la distracción. En un ritmo de pasosyde detenciones:complejidady densidad de formas que acompañan, almododel perfildela ciudad quese presenta a los ojos de quien la contempla. Situación que requiere distancias, es por ello que dijimos extensión. En el campo poético, podemos preguntarnos si el poema de Dante Alighieri, La divina comedia, es un paseo. Aquello que comienza relatando:

"En medio del camino de la vida

Yo me encontré en una selva obscura,

Porque la recta vía había perdido.

iAh, cuán duro es decir cuál se mostraba esta selva áspera y fuerte,

Que aún en la mente el pavor renueva!"

Este poema nos expone el paso guiado, que trae la posibilidad del encuentro. También en la plástica, es pertinente detenerse ante Las cárceles, grabados de Piranesi. Con líneas bien resueltas, observamos en sus grabados la invención de un espacio en el que construye lejanías con la misma potencia de lo próximo. Lo lejano no es periferia, puesto que fija la luminosidad con la que ilumina lo próximo, dando existencia a un espacio holgado en el que se habita la tierra y el cielo. Son umbrales donde intercala masa y luz, conformando espacios entre.

\section{Leisure and Architecture}

Patricio Cáraves Professor, Pontificia Universidad Católica de Valparaíso

The characteristic acts of leisure and it way of occupying space are varied. Their observation by architects gives place to specific named spaces. From different areas of art ways of giving a home to leisure are illustrated.

To address leisture in architecture one must see it in an act and in reference to work. It requires one to freely designate time to its contemplation.

In leisure, one seeks to be in a clear but sheltered space, that is, to give structure to three dimensional space, permitting co-existence of the distant with the nearby. Let's look at this, something lived by many, and such, a common occurence: two friends or a couple taking a walk. In describing it we can note, for example, walking without haste, as wanting to completely plant ones foot with each step. Conversing distractedly, in a free attempt to say the words calmly, in that each syllable is distinguished. Looking at one's everday, intimate environment, the landscape of a family outing, free from anything that could cause tension.

Coming and going, hearing and speaking, stopping to smell the flowers, seeing a continuity of distance and nearness. Touching whatever the hand meets. All with a kind of distraction, under a light tinged by the protection of trees. One passes confidently through space, open to the pleasure to be enjoyed through extension.

In this act of walking we can be on the beach by the sea, or in a parque, that is, in nature. The diversity of spaces for this act is broad. Until this moment architecture has not yet entered the picture.

So now we ask ourselves, how does architecture protect leisure?

The architectural profession begins by observing this act of taking a walk we described; it becomes present, the act of walking. To give home to the act of relaxation that is taking a walk, in the complete aperture of meanings, must consider the characteristics of the person walking. To carry out this task one must pay attention to everything. Everything that occurs is observed. One begins naming to give form to the extensive form and designates orientation. The oriented extension, we must understand it as the complexity of the form that protects the eye, invites the fooy to take steps in the distraction.

In a rhythm of steps and pauses: the accompaning complexity and density, like of the city skyline that is presented to the eyes and is contemplated. Situation that requires distances is what we mean when we say extension. In the poetic field, we can ask if the poem of Dante Alighieri, The Divine Comedy, is a walk. That begins by saying:

"Midway upon the journey of our life

I found myself within a forest dark

For the straightforward pathway had been lost.

Ah me! how hard a thing it is to say what was this forest savage, rough, and stern,

Which in the very thought renews the fear."

This poem shows us the guided step that presents the possibility of a meeting. Also in the plastic, it is pertinent to pause before The prisons, prints by Piranesi. With its well defined lines, we see the invention of a space in which the background has the same intensity as the foreground. The distanct is not the periphery, placed so that there luminosity is fixed with the luminosity of the near, thus giving existence to an accomodating space in which both earth and sky inhabit. They are thresholds that insert mass and light, making space. 


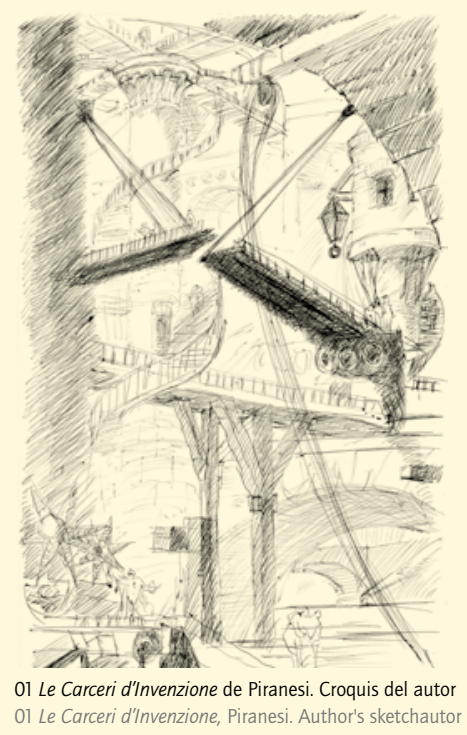

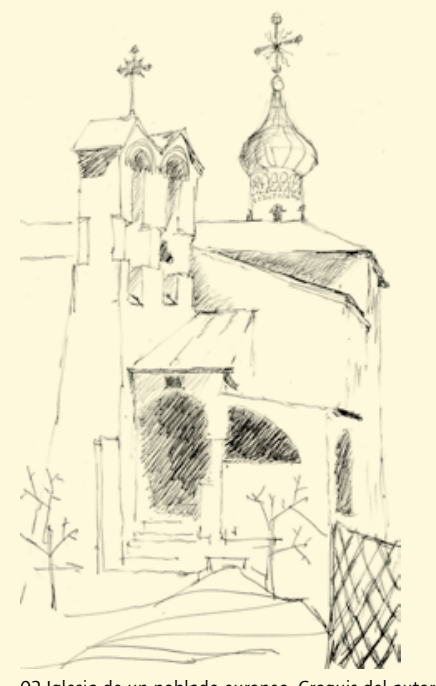

02 Iglesia de un poblado europeo. Croquis del auto 02 Church and bell tower of a european town. Author's sketch

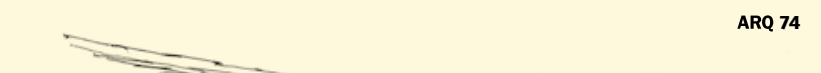

A lo expuesto hasta aquí, debemos complementarlo con lo siguiente: el paseo que guarda al ocio en el espacio, donde todo es objeto de detención.

Para dar con estas exigencias, que exceden a las necesidades programáticas, se requiere de la gratuidad. Los arquitectos que proyectan un espacio cuyo programa es el paseo, tienen presente el realizar algo que es pura donación, no sólo para ser visto, sino que para dar encuentro y ser encontrado.

Para ilustrar esta presencia gratuita donada al encuentro, traigamos un hecho relatado:

De una antigua iglesia de un poblado europeo debieron retirar una vieja campana, desde su espaldaña, para proceder a su reparación. En la faena de desmontarla, los obreros se sorprendieron al ver que en el interior de la campana estaba grabada una oración, escrita en latín con la perfección de la letra de caja. Perfección y gratuidad, guardada para ser encontrada.

Pero lo complejo del espacio que conforma al acto del paseo, que acoge al ocio, requiere de más dimensiones. Se requiere de la invención, de inventar para nutrir la contemplación. Para ello es preciso hacer venir lo que no estaba. Aquí, nos referimos a una acción con la cual se introduce en el espacio un cuerpo que, sin ser ajeno, lo singulariza y lo re-crea. Para clarificar esta faena, puede ser oportuno traer un ejemplo notable: en la Alemania medieval, en la localidad de Limburg próxima a la catedral de Spira, en el costado poniente de la explanada, el emperador Conrado II mandó construir un largo y esbelto muro de mar -gradierwerke-, edificación en madera de gran sección cargada con ramas de espinoy que luego recubren con sal gruesa de mar. Es un muro que, enfrentando al viento predominante, lo deja pasar atenuándolo y cargándolo de sal, transformándolo finalmente en brisa de mar. El que por allí paseare, lo haría acompañado por la presencia lejana del mar.

Recapitulando, tenemos una forma de dar casa al ocio, bien puede ser con el acto del paseo. Y este está conformado por la correspondencia de las lejanías con la proximidad, en una relación que ampara dando casa con gratuidad, perfección e invención.

El arquitecto se pregunta: "idónde se encuentra el ocio?"Y se responde: "en un paseo." Porque éste es el lugar que reúne excelencias: desplazarse sin prisa; se va por una extensión conocida y sin amenazas; hay un aire aromatizado; se está bajo la luz templada de un follaje; es una extensión no constreñida junto al mar o un parquey, finalmente, el paseo hace del ocio un acto, donde se reúne el pie y el ojo al desplazarse, junto a la palabra que es decir y oír.

El espacio del paseo se lo puede reconocer en la obra plástica de Piranesi, Las cárceles, donde la lejanía y la proximidad, igualmente construidas por la luz, edifican un espacio holgado para ser habitado por la mirada.

Este espacio es posible porque quien practica y acoge el ocio requiere de la gratuidad. La gratuidad entendida como ese mayor esfuerzo y dedicación llevado a la forma, que hace de una construcción una obra. Y se lo puede nombrar como gratuidad porque la forma lograda no espera un inmediato reconocimiento.

Por último, la arquitectura del paseo incluye un artificio, realiza una invención en el sentido de traer lo que antes no estaba, como la recreación de la brisa marina en un lugar distante del mar, trayendo la lejanía al presente con el aroma de la sal. $\mathrm{Al}$ ocio se lo puede concebir como la capacidad del hombre de disfrutar el mundo que construye. Y esto se da en un acto que se consuma en sí mismo, que celebra su existencia completándose, al modo del rezo de las completas en la vigilia de las horas, con lo que se da término al día vivido en gracia. ARQ
With this, the following must be said as a complement: the walk that protects leisure in space, where everything is an object of pause.

To acheive these demands that exceed programmatic necessities, gratuity is required. The architects that create a space whose program is the walk are aware that it must be a pure donation, to give a meeting place and be found.

To illustrate this gratuitous presence donated to the meeting place, we bring a related fact:

In an old church of a European town they must take down an old bell from its tower to proceed with repairs. In the act of taking it down, the workers were surprised to find an inscription on the interior of the bell, written in latin in perfect type. Perfection and gratuity, hidden to be found, understood as the opposite of exhibition.

But the complexity of the space conforming the walk, that embraces leisure, requires more dimensions. It requires invention to nourish contemplarion. For this, it is necessary to bring what was not there. Here, we refer to an accion with which a body is introduced to the space that, without being alien, both recreates and singularizes it. To clarify this task, it would be opportune to present this notable example: in medieval Germany, in the city of Limburg near the Spira cathedral, on the east side of the plaza, Emperor Conrad II commissioned a long, thin sea wall-gradierwerke-, a heavy timber structure made of pine and later covered with sea salt. In a wall that, facing a predominate wind, it passes over it and covering it with salt, finally transforming it in a sea breeze. If someone walks along this wall, they would be accompanied by the distant presence of the sea.

In summary, we have a way to give home to leisure, which could be the act of taking a walk. And the act of walking is conformed by the correspiondence of the distant with the near, in a relationship that protects with gratuity, perfection and invention.

The architect is asked: "where does one find leisure?" And he responds: "on a walk". Because this is the place that reunites excellencies: moving without haste, it goes through a known extension and without threats, with fragrant air, under the light shaded by the trees, an extension without restriction together with the sea or a park, and finally, the walk takes leisure and makes it an act where the foot and the eye move together with hearing and seeing.

The space of the walk can be recognized in the plastic works of Piranesi, The Prisons, where the distant and the near, equally constructed by light, build a space to be inhabitated by the looker.

The space of the walk is possible because he who practices and embraces leisure requires gratuity. The gratuity understood as this greater force and dedication carried out in the construction of a project. And it can be called gratuity because the acheived form does not seek immediate recognition.

Lastly, the architecture of the walk includes a device, realizes an invention in the meaning of bring what was not there before, like the enjoyment of the sea breeze in a place far from the sea, bringing the far-away to the present with the smell of the salt.

Leisure can be conceived as the capacity of man to enjoy the world he builds. And this is given in an act that consumes itself, that celebrates its existence completing itself like the prayers de las completas at the end of the day giving an end to another day lived with grace. 